\title{
Evaluation Grid for RDM Policies in Europe
}

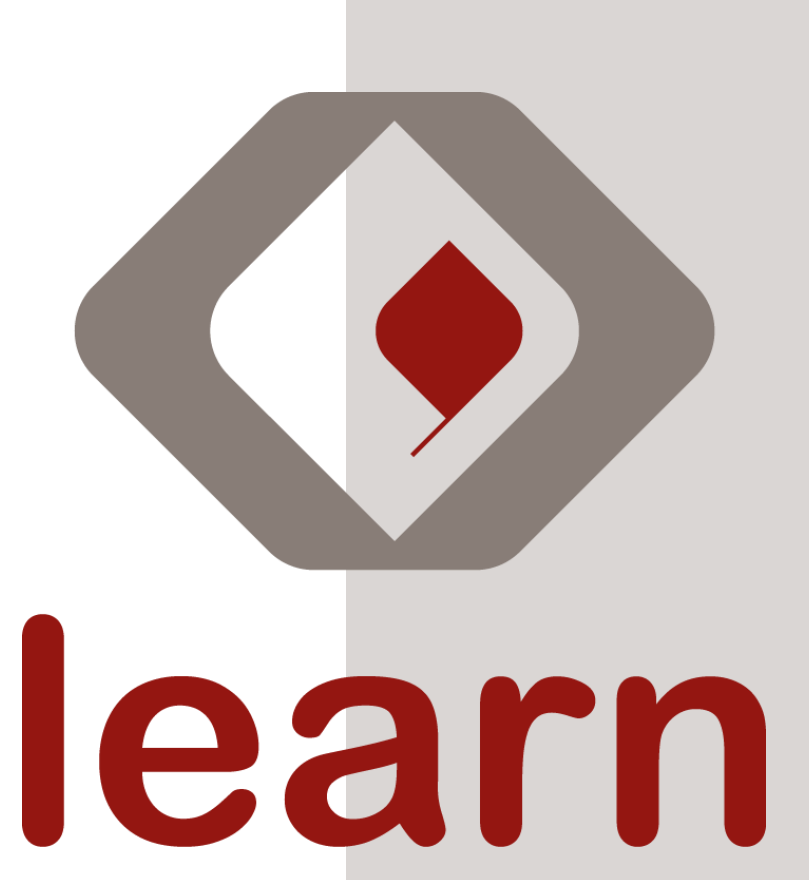

LEARN | WP3 - University of Vienna Version 1.0 (to be reviewed) 


\section{Evaluation of RDM Policies}

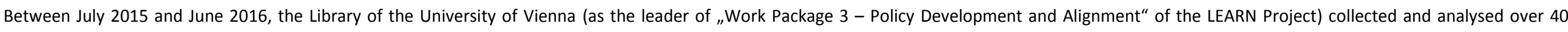

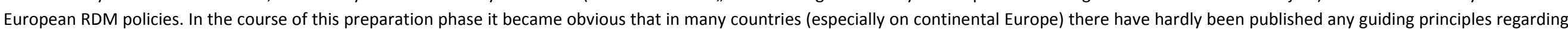

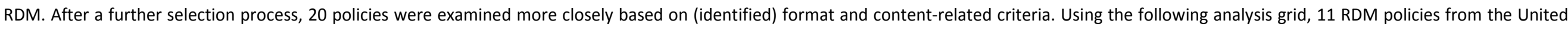

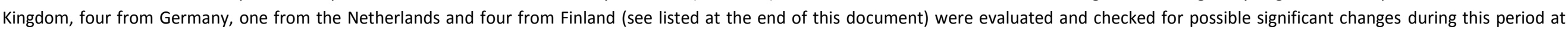
regular intervals. This compact overview is also supplemented by a detailed evaluation of the selected policies with extensive comments (see below).

\begin{tabular}{|c|c|c|c|}
\hline Criteria & \multicolumn{3}{|c|}{ Status - Overview } \\
\hline Number of institutions: $\mathbf{2 0}$ & It was NOT taken into consideration & It was PARTLY taken into account & It has been CONSIDERED \\
\hline 1. $\quad$ Authorship. & III & H11+111III & 1111 \\
\hline 2. Validity & II & $\mathrm{HIHHH} \mathrm{II}$ & $\mathrm{HH} \mathrm{I}$ \\
\hline 3. Review & HWHHII & III & HH \\
\hline 4. Subject & & 1111 & $\mathrm{HHHHHHI}$ \\
\hline 5. Scope and coverage & & $\mathrm{HH} \mathrm{II}$ & HIHHIIII \\
\hline 6. $\quad$ Preliminaries and definitions & II & HH & HWHWIII \\
\hline 7. Institutional awareness, support and services & & $\mathrm{HH}$ II & H1HHWIII \\
\hline 8. Objectives ("what and how") & & HHHH III & $\mathrm{HHII}$ \\
\hline 9. Roles and responsibilities & & $\mathrm{HIHIIII}$ & $\mathrm{HHHH}$ \\
\hline 10. DMP & 1 & III & $\mathrm{HHHHHHI}$ \\
\hline 11. Costs & $\mathrm{HH}$ II & $\mathrm{HHHH}$ & III \\
\hline 12. External & IIII & HHIII & HHIII \\
\hline 13. Ownership & $\mathrm{HH}$ & $\mathrm{HIIIII}$ & $\mathrm{HH}$ \\
\hline 14. Retention & $\mathrm{HHHH}$ & IIII & $\mathrm{HH} \mathrm{I}$ \\
\hline 15. Deletion & $\mathrm{HHHHHHII}$ & II & 1 \\
\hline 16. Legal aspects & & $\mathrm{HH} I \mathrm{II}$ & $\mathrm{HHHHII}$ \\
\hline 17. Ethics & 11 & HIIIIII & $H H I I I I$ \\
\hline 18. Open data / restricted data / closed data & II & $\mathrm{HIHHHII}$ & $\mathrm{HHI}$ \\
\hline 19. Storage and access & 1 & $\mathrm{HHH} I \mathrm{II}$ & $\mathrm{HHHHI}$ \\
\hline 20. Metadata curation & $\mathrm{HIHIII}$ & 1111 & $\mathrm{HIHIII}$ \\
\hline 21. Exceptions & $\mathrm{HH} I \mathrm{II}$ & $\mathrm{HH}$ & $\mathrm{HH} \mathrm{II}$ \\
\hline 22. Research infrastructure & $\mathrm{HHHH}$ & $\mathrm{HH}$ & $\mathrm{HH}$ \\
\hline 23. Long tail of data / head of project data & H1HH1HH1H III & II & \\
\hline 24. Educational data & $\mathrm{HHHHHHH}$ & & \\
\hline 25. Cultural heritage & HHHHHH HH & & \\
\hline
\end{tabular}


Criteria

Status - Detail

\begin{tabular}{|c|c|c|c|c|}
\hline Number of institutions: 20 & $\begin{array}{l}\text { It was NOT taken } \\
\text { into consideration* }\end{array}$ & $\begin{array}{l}\text { It was PARTLY taken } \\
\text { into account* }\end{array}$ & $\begin{array}{l}\text { It has been } \\
\text { cONSIDERED* }\end{array}$ & Comments \\
\hline $\begin{array}{l}\text { 1. Authorship. It should } \\
\text { be clear who defines } \\
\text { the policy }\end{array}$ & $\begin{array}{c}\text { University of Bath } \\
* \\
\text { Universität Bielefeld } \\
* \\
\text { Universität Heidelberg }\end{array}$ & $\begin{array}{l}\text { STFC } \\
\text { University of Birmingham } \\
\text { University of Bristol } \\
\text { University of Cambridge } \\
\text { University of Edinburgh } \\
\text { University of Glasgow } \\
\text { University of Leeds } \\
\text { University of the Arts } \\
\text { London } \\
\text { Aalto University } \\
\text { University of Helsinki } \\
\text { Radboud University } \\
\text { Humboldt-Universität zu } \\
\text { Berlin } \\
\text { Universität Göttingen }\end{array}$ & $\begin{array}{c}\text { UCL } \\
* * \\
\text { University of Oxford } \\
\text { Tampere University of } \\
\text { Technology } \\
\text { University of Turku }\end{array}$ & $\begin{array}{l}\text { STFC : Drawn up by an internal technical working group (information only on the website, not in the document) } \\
\text { UCL : Author mentioned by name } \\
\text { University of Bristol : Approved by Senate | Well-defined authorship only in the previous draft version, not in the } \\
\text { updated document } \\
\text { University of Cambridge : Approved by Research Policy Committee } \\
\text { University of Edinburgh : Approved by University Court | RDM Roadmap: authors meintioned by name } \\
\text { University of Glasgow : Information only on the website, not in the document | Approved by Research Strategy } \\
\text { and Planning Committee } \\
\text { Tampere University of Technology : Detailed description of working process | Working group chaired by Vice } \\
\text { President for Research } \\
\text { University of Turku : Decision of the Rector } \\
\text { Radboud University : Poor information on the authorship (Executive Board) } \\
\text { Humboldt-Universität zu Berlin : Approved by Academic Senat }\end{array}$ \\
\hline $\begin{array}{l}\text { 2. Validity. The date of } \\
\text { the release of the } \\
\text { policy should be clear. } \\
\text { It should also be clear } \\
\text { how long the terms of } \\
\text { the policy are valid. }\end{array}$ & $\begin{array}{l}\text { STFC } \\
{ }_{*}^{*} \\
\text { University of the Arts } \\
\text { London }\end{array}$ & $\begin{array}{l}\text { University of Birmingham } \\
\text { University of Bristol } \\
\text { University of Cambridge } \\
\text { University of Glasgow } \\
\text { University of Leeds } \\
\text { University of Oxford } \\
\text { Tampere University of } \\
\text { Technology } \\
\text { University of Helsinki } \\
\text { Humboldt-Universität zu } \\
\text { Berlin }\end{array}$ & $\begin{array}{c}\text { UCL } \\
\text { University of Bath } \\
\text { University of Edinburgh } \\
\text { Aalto University } \\
\text { University of Turku } \\
\text { Radboud University }\end{array}$ & $\begin{array}{l}\text { UCL : Approving policy | Ensuring resources | Implementation } \\
\text { University of Bath : Date of last modification is indicated } \\
\text { University of Cambridge : Date of last modification is indicated | "The University acknowledges that a full } \\
\text { implementation of this policy framework will be a long-term process." } \\
\text { University of Edinburgh : Aspirational policy: implementation will take some years | | RDM Roadmap: Timeframe } \\
\text { August } 2012 \text { - July } 2016 \\
\text { University of Glasgow : Information about release only available on the website, not in the document } \\
\text { University of Leeds : Institutional RDM Policy Evolution on the website } \\
\text { University of Turku : Realisation is followed with indicators | Policy and implementation are developed } \\
\text { Universität Bielefeld : Information about release only available on accompanied webpage "Resolution on RDM" } \\
\text { Universität Göttingen : Information about release only available on the website, not in the document }\end{array}$ \\
\hline
\end{tabular}




\begin{tabular}{|c|c|c|c|c|}
\hline & & $\begin{array}{l}\text { Universität Bielefeld } \\
\text { Universität Göttingen } \\
\text { Universität Heidelberg }\end{array}$ & & Universität Heidelberg : Date of last modification is indicated \\
\hline $\begin{array}{l}\text { 3. Review. The policy } \\
\text { should be a subject to } \\
\text { periodic review }\end{array}$ & 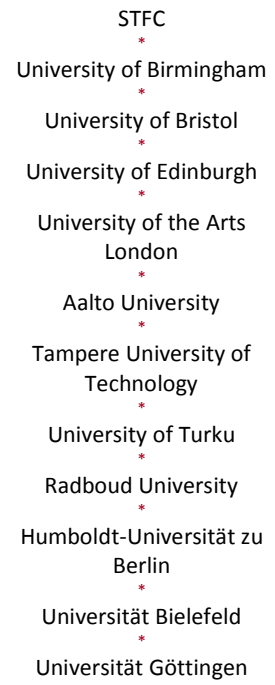 & $\begin{array}{l}\text { University of Glasgow } \\
\text { University of Helsinki } \\
\text { Universität Heidelberg }\end{array}$ & $\begin{array}{l}\text { UCL } \\
\text { University of Bath } \\
\text { University of Cambridge } \\
\text { University of Leeds } \\
\text { University of Oxford }\end{array}$ & $\begin{array}{l}\text { UCL : Reviewed at least every } 3 \text { years by RIISG and UCL Research Data and Network Services Executive } \\
\text { University of Bristol : Revision History only in the previous draft version, not in the updated document } \\
\text { University of Cambridge : Regularly reviewed by the Open Access Project Board } \\
\text { University of Glasgow : Information on website: "This policy replaces the previous Draft" } \\
\text { University of Leeds: Research and Innovation Board is responsible for reviewing and updating the policy } \\
\text { University of Oxford: Research and Information Sub-Committee is responsible for updating of the policy }\end{array}$ \\
\hline $\begin{array}{l}\text { 4. Subject. It should be } \\
\text { clear what the subject } \\
\text { of the policy is }\end{array}$ & & $\begin{array}{l}\text { University of Birmingham } \\
\text { University of Edinburgh } \\
\text { Universität Bielefeld } \\
\text { Universität Heidelberg }\end{array}$ & $\begin{array}{c}\text { STFC } \\
\text { UCL } \\
\text { University of Bath } \\
\text { University of Bristol } \\
\text { University of Cambridge } \\
\text { University of Glasgow } \\
\text { University of Leeds } \\
\text { University of Oxford } \\
\text { University of the Arts } \\
\text { London } \\
\text { Aalto University } \\
\text { Tampere University of } \\
\text { Technology } \\
\text { University of Helsinki } \\
\text { University of Turku }\end{array}$ & \\
\hline
\end{tabular}




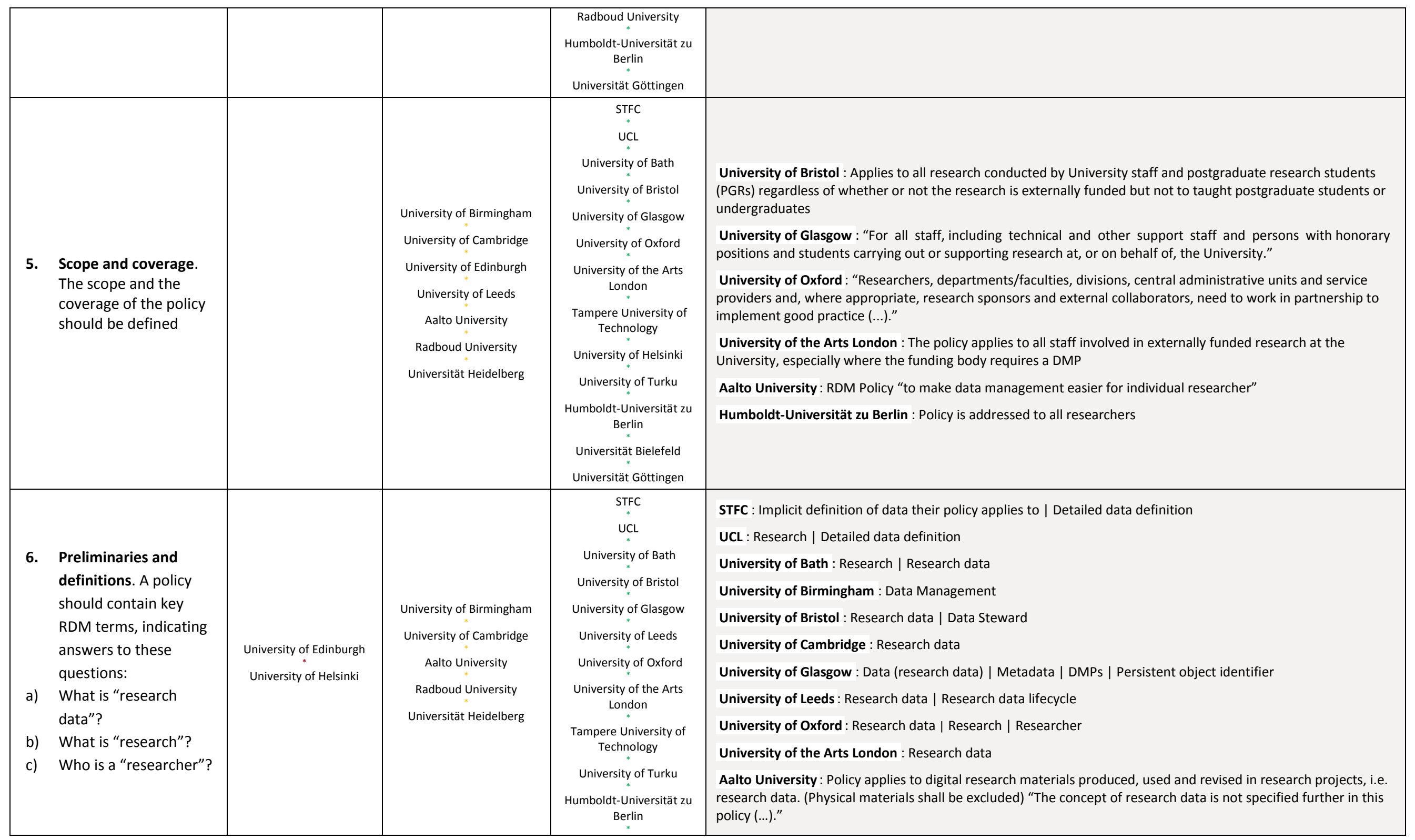




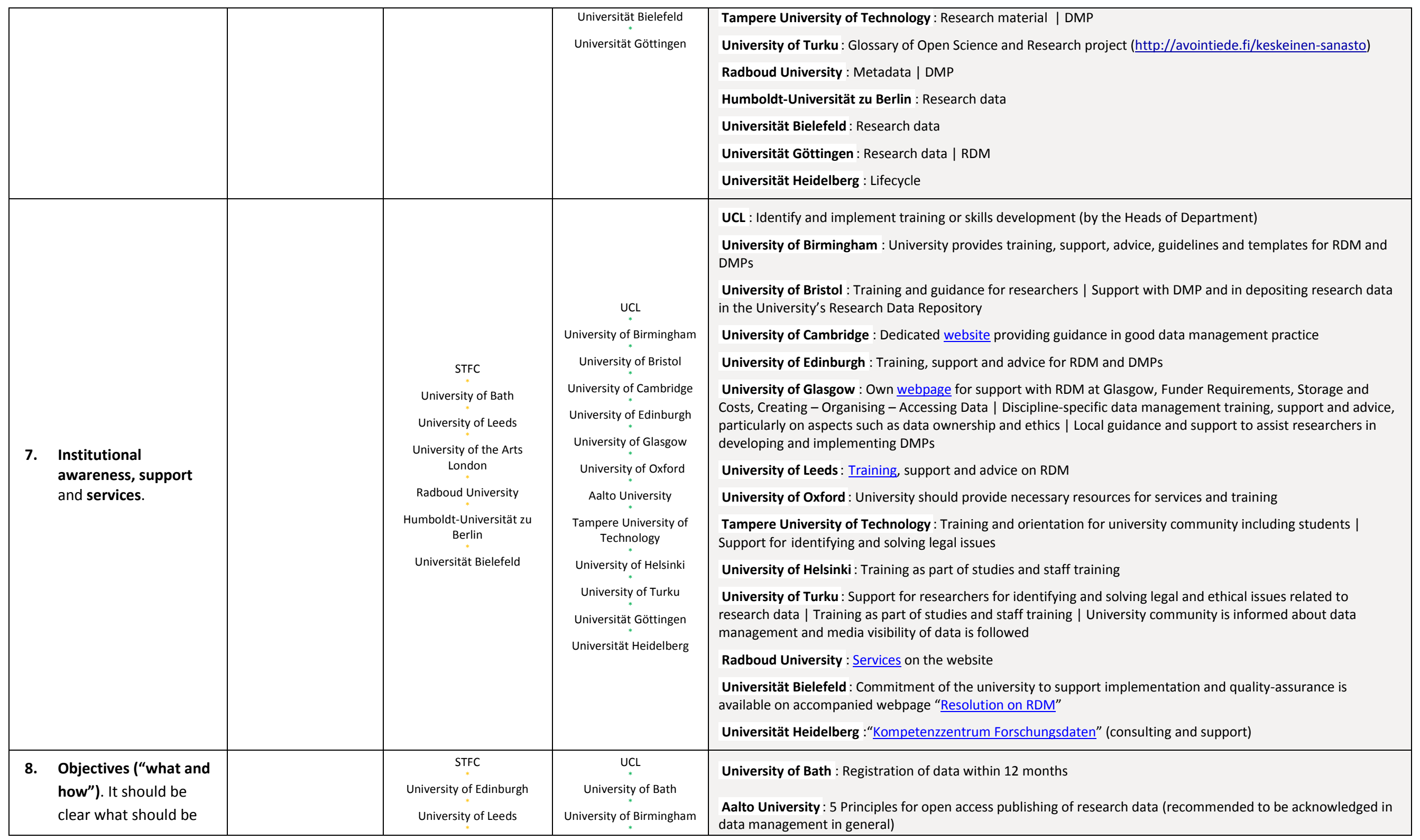




\begin{tabular}{|c|c|c|c|c|}
\hline & $\begin{array}{l}\text { done and how it should } \\
\text { be done }\end{array}$ & $\begin{array}{l}\text { University of Oxford } \\
\text { University of the Arts } \\
\text { London } \\
\text { Tampere University of } \\
\text { Technology } \\
\text { University of Helsinki } \\
\text { University of Turku } \\
\text { Radboud University } \\
\text { Humboldt-Universität zu } \\
\text { Berlin } \\
\text { Universität Bielefeld } \\
\text { Universität Göttingen } \\
\text { Universität Heidelberg }\end{array}$ & $\begin{array}{c}\text { University of Bristol } \\
\text { University of Cambridge } \\
\text { University of Glasgow } \\
\text { Aalto University }\end{array}$ & \\
\hline b) & $\begin{array}{l}\text { Roles and } \\
\text { responsibilities. } \\
\text { Definition of the } \\
\text { responsibilities, tasks } \\
\text { and instruments, of: } \\
\text { the researchers / P.I. } \\
\text { (data producing entity) } \\
\text { research supporting } \\
\text { entities (e.g. research } \\
\text { services, libraries, IT } \\
\text { services } \\
\text { the institution }\end{array}$ & $\begin{array}{l}\text { STFC } \\
\text { University of Edinburgh } \\
\text { University of Leeds } \\
\text { Aalto University } \\
\text { Tampere University of } \\
\text { Technology } \\
\text { University of Helsinki } \\
\text { University of Turku } \\
\text { Humboldt-Universität zu } \\
\text { Berlin } \\
\text { Universität Heidelberg }\end{array}$ & $\begin{array}{l}\text { UCL } \\
\text { University of Bath } \\
\text { University of Birmingham } \\
\text { University of Bristol } \\
\text { University of Cambridge } \\
\text { University of Glasgow } \\
\text { University of Oxford } \\
\text { University of the Arts } \\
\text { London } \\
\text { Radboud University } \\
\text { Universität Bielefeld } \\
\text { Universität Göttingen }\end{array}$ & $\begin{array}{l}\text { UCL : Detailed description of responsibilities | Students as Data Creators | UCL Research Data Service } \\
\text { University of Bath : e.a. Data Stewart | Data loss | Contact for queries } \\
\text { University of Birmingham : PI | Researchers | Students | University | All those undertaking research within the } \\
\text { University (including students) has a responsibility to manage their data effectively } \\
\text { University of Bristol : Researchers | PI | Data Steward | Postgraduate Research Students and Supervisor | } \\
\text { University } \\
\text { University of Cambridge : University | University staff and students } \\
\text { University of Edinburgh : PI | University } \\
\text { University of Glasgow : Researchers | School and College Level Support | University Services } \\
\text { University of Leeds: Responsible owners | PI | University | Researchers | Research and Innovation Board } \\
\text { University of Oxford: Researchers | University } \\
\text { University of the Arts London : University | PI | Director of Research Management and Administration (RMA) | } \\
\text { Research assistants | } \\
\text { Radboud University : Researcher | Project leader | Director of research institute | Director of education | } \\
\text { University } \\
\text { University of Turku : Each university community member } \\
\text { Humboldt-Universität zu Berlin : Obligation of researchers includes instructing students and doctoral candidates } \\
\text { about handling of research data properly | "Researchers should take responsibility for deciding at what time and } \\
\text { on what legal terms research data may be accessed." } \\
\text { Universität Bielefeld: Researcher | PI | Rektorat (on accompanied webpage "Resolution on RDM") }\end{array}$ \\
\hline
\end{tabular}




\begin{tabular}{|c|c|c|c|c|c|}
\hline & & & & & $\begin{array}{l}\text { Universität Göttingen : PI | Researcher | University } \\
\text { Universität Heidelberg :: PI | University }\end{array}$ \\
\hline & $\begin{array}{l}\text { DMP. The policy should } \\
\text { specify a requirement } \\
\text { to complete a DMP } \\
\text { (either institutional or } \\
\text { funder) }\end{array}$ & $\begin{array}{l}\text { Humboldt-Universität zu } \\
\text { Berlin }\end{array}$ & $\begin{array}{l}\text { University of Oxford } \\
\text { University of the Arts } \\
\text { London } \\
\text { Aalto University }\end{array}$ & $\begin{array}{c}\text { STFC } \\
\text { UCL } \\
\text { University of Bath } \\
\text { University of Birmingham } \\
\text { University of Bristol } \\
\text { University of Cambridge } \\
\text { University of Edinburgh } \\
\text { University of Glasgow } \\
\text { University of Leeds } \\
\text { Tampere University of } \\
\text { Technology } \\
\text { University of Helsinki } \\
\text { University of Turku } \\
\text { Radboud University } \\
\text { Universität Bielefeld } \\
\text { Universität Göttingen } \\
\text { Universität Heidelberg }\end{array}$ & $\begin{array}{l}\text { STFC : Consistent with DMPs of other facilities | National and international recommendations for best practice } \\
\text { (DCC guidance) } \\
\text { University of Birmingham : From 2015, all new research proposals must include DMPs or protocols } \\
\text { University of Bristol : DMP should be written before research commences | DMP guidance for specific funders on } \\
\text { website | DMP template for PGR students - DMP online tool by DCC } \\
\text { University of Cambridge : Guidance by University of Cambridge and DCC | If funders require a DMP, such plan } \\
\text { needs to be prepared according to funders' requirements | Researchers should update their DMPs regularly, } \\
\text { ensure that at the end of the project all their research outputs, together with their location, are indicated in their } \\
\text { DMPs and deposit their final DMPs into an appropriate repository } \\
\text { University of Edinburgh : All new research proposals must include DMPs } \\
\text { University of Glasgow : Researchers have to produce DMP for every research project that will generate a dataset } \\
\text { University of Leeds: DMP must be created for each proposed research project or funding application to allow } \\
\text { costing and infrastructure planning. Once project is approved DMP should be updated }\end{array}$ \\
\hline & $\begin{array}{l}\text { Costs. Questions } \\
\text { around the costs of } \\
\text { RDM should be well } \\
\text { defined }\end{array}$ & $\begin{array}{c}\text { University of Edinburgh } \\
\text { University of Oxford } \\
*^{*} \\
\text { University of the Arts } \\
\text { London } \\
* \\
\text { Radboud University } \\
*_{*}^{*} \\
\text { Humboldt-Universität zu } \\
\text { Berlin } \\
* \\
\text { Universität Bielefeld } \\
* \\
\text { Universität Heidelberg }\end{array}$ & $\begin{array}{c}\text { STFC } \\
\text { UCL } \\
\text { University of Birmingham } \\
\text { University of Cambridge } \\
\text { University of Glasgow } \\
\text { Aalto University } \\
\text { Tampere University of } \\
\text { Technology } \\
\text { University of Helsinki } \\
\text { University of Turku } \\
\text { Universität Göttingen }\end{array}$ & $\begin{array}{l}\text { University of Bath } \\
\text { University of Bristol } \\
*_{*}^{*} \\
\text { University of Leeds }\end{array}$ & $\begin{array}{l}\text { STFC : Efficient and cost-effective research | Appropriate to use public funds } \\
\text { University of Birmingham : Researchers should seek to cover direct costs of RDM from research funder | DMP } \\
\text { will include costing RDM } \\
\text { University of Bristol : Time and any likely cost for storage and management should be explicitly written into } \\
\text { research applications, including instances where data will need to be made publicly available or curated for many } \\
\text { years beyond the project lifetime. | Funders: costs relating to storage and management of research data are } \\
\text { legitimate costs and can be included within a research proposal. These costs can generally only cover the lifetime } \\
\text { of the grant so any work needed to make the data available for sharing at the end of the project should be built } \\
\text { into the proposal. | Research Data Service's Anticipating the costs of RDM document | Potential costs for larger } \\
\text { deposit } \\
\text { University of Glasgow : Costs are not mentioned in the policy, but on the website: "Cost of storing data (...): } \\
\text { Research Data is } f 1800 \text { per-terabyte (excluding VAT). This is a one-off charge and guarantees secure data storage } \\
\text { for ten years. " } \\
\text { University of Leeds: Guide for costing and infrastructure planning is available on the website. Researchers should } \\
\text { seek to recover the direct costs of managing research data generated by projects from the research funder }\end{array}$ \\
\hline
\end{tabular}




\begin{tabular}{|c|c|c|c|c|c|}
\hline & & & & & $\begin{array}{l}\text { Aalto University : Opening access to research data shall be implemented in a cost-effective manner } \\
\text { Radboud University : "Previous research suggests that a centralised service for data management at Radboud } \\
\text { University would bemore cost effective than management at an institutional level." } \\
\text { Universität Göttingen : "Specific requirements have to be aligned among all stakeholders and may involve } \\
\text { additional funding." }\end{array}$ \\
\hline & $\begin{array}{l}\text { External. The policy } \\
\text { should contain a } \\
\text { statement on the } \\
\text { primacy of external } \\
\text { funding requirements } \\
\text { and about external } \\
\text { research partners }\end{array}$ & $\begin{array}{c}\text { Tampere University of } \\
\text { Technology } \\
{ }_{*} \\
\text { University of Turku } \\
{ }^{*} \\
\text { Humboldt-Universität zu } \\
\text { Berlin } \\
* \\
\text { Universität Göttingen }\end{array}$ & $\begin{array}{l}\text { University of Edinburgh } \\
\text { University of Leeds } \\
\text { University of the Arts } \\
\text { London } \\
\text { Aalto University } \\
\text { University of Helsinki } \\
\text { Radboud University } \\
\text { Universität Bielefeld } \\
\text { Universität Heidelberg }\end{array}$ & $\begin{array}{c}\text { STFC } \\
\text { UCL } \\
\text { University of Bath } \\
\text { U* } \\
\text { University of Birmingham } \\
\text { University of Bristol } \\
*_{*} \\
\text { University of Cambridge } \\
\text { University of Glasgow } \\
\text { University of Oxford }\end{array}$ & $\begin{array}{l}\text { UCL : Collaborative research } \\
\text { University of Birmingham : Data retained elsewhere should also be recorded with University | Funder-compliant } \\
\text { storage | Third-party Intellectual Property rights in "Code of Practice for Research" ( } 3 \text { Research Data) } \\
\text { University of Bristol : Where research is carried out under a grant or contract: terms of agreement will determine } \\
\text { ownership and rights to exploit the data | External research partners | Third party funded research data of PGRs } \\
\text { should be passed on to supervisor before the student leaves the University } \\
\text { University of Cambridge : “The University is committed to achieving compliance with the data policies of its } \\
\text { external research sponsors, publishers and governmental agencies, and requires its staff and students to abide by } \\
\text { terms and conditions agreed with third parties. The University also recognises that such third parties' policies are } \\
\text { evolving and that they may require higher levels of data accessibility and dissemination in the future." } \\
\text { University of Edinburgh : Data retained elsewhere should be registered with the University } \\
\text { University of Glasgow : Data retained elsewhere should also be recorded with University data registry I } \\
\text { Researchers have to "familiarise themselves with relevant funder data policies and expectations and endeavour to } \\
\text { comply with these policies." } \\
\text { University of Leeds: Research Funder data requirements available on the website I Data held outside the } \\
\text { University should be recorded in the University data registry } \\
\text { University of Oxford: Overview of major research funders' data policies (DCC) } \\
\text { Universität Heidelberg : Data retained elsewhere should also be recorded with the University }\end{array}$ \\
\hline 13. & $\begin{array}{l}\text { Ownership. The } \\
\text { questions concerning } \\
\text { the ownership of } \\
\text { research data should } \\
\text { be taken into } \\
\text { consideration }\end{array}$ & $\begin{array}{c}\text { University of Edinburgh } \\
{ }_{* *} \\
\text { University of the Arts } \\
\text { London } \\
* \\
\text { Radboud University } \\
\text { Universität Bielefeld } \\
* \\
\text { Universität Göttingen }\end{array}$ & $\begin{array}{l}\text { STFC } \\
\text { UCL } \\
\text { University of Birmingham } \\
\text { University of Cambridge } \\
\text { University of Leeds } \\
\text { University of Oxford } \\
\text { Tampere University of } \\
\text { Technology } \\
\text { University of Turku } \\
\text { Humboldt-Universität zu } \\
\text { Berlin } \\
\text { Universität Heidelberg }\end{array}$ & $\begin{array}{l}\text { University of Bath } \\
\text { University of Bristol } \\
\text { University of Glasgow } \\
\text { Aalto University } \\
\text { University of Helsinki }\end{array}$ & $\begin{array}{l}\text { UCL : Owner is responsible for preserving research data } \\
\text { University of Bath : Student's data } \\
\text { University of Birmingham : in "Code of Practice for Research" ( } 3 \text { Research Data) } \\
\text { University of Bristol : } \\
\text { - Where research is carried out under a grant or contract: terms of agreement will determine ownership } \\
\text { - Where no external contract exists: University normally has ownership of primary data generated in the } \\
\text { course of research undertaken by researchers in its employment } \\
\text { I Suitable agreements for ownership should be established and agreed in writing by parties concerned before a } \\
\text { project starts } \\
\text { University of Glasgow : Researchers have to: } \\
\text { - "Clearly state who owns the data that are being generated through the research activity. Where this is not }\end{array}$ \\
\hline
\end{tabular}




\begin{tabular}{|c|c|c|c|c|c|}
\hline & & & & & $\begin{array}{l}\text { clear, researchers will work with IPR specialists in Research Strategy and Innovation, the Library and College } \\
\text { support teams to verify data ownership as early as possible in the research data lifecycle." } \\
\text { "Ensure that, when leaving the University (for retirement or a position elsewhere), data of long-term value } \\
\text { which were generated using University resources are deposited in the Institutional Data Repository for long- } \\
\text { term storage and preservation." } \\
\text { University of Leeds: Responsibilities of the responsible owners } \\
\text { Aalto University: Ownership of copyright protected research data is transferred to the University if the data is } \\
\text { created in externally funded research project of the University }\end{array}$ \\
\hline & $\begin{array}{l}\text { Retention. The length } \\
\text { of time and criteria on } \\
\text { what research data is } \\
\text { required to be kept, } \\
\text { should be defined. }\end{array}$ & $\begin{array}{c}\text { University of Glasgow } \\
\text { University of Leeds } \\
\text { University of the Arts } \\
\text { London } \\
\text { Aalto University } \\
\text { * } \\
\text { Tampere University of } \\
\text { Technology } \\
\text { University of Helsinki } \\
\text { University of Turku } \\
\text { Universität Bielefeld } \\
\text { Universität Göttingen } \\
\text { * } \\
\text { Universität Heidelberg }\end{array}$ & $\begin{array}{l}\text { University of Birmingham } \\
\text { University of Cambridge } \\
\text { University of Edinburgh } \\
\text { Humboldt-Universität zu } \\
\text { Berlin }\end{array}$ & $\begin{array}{c}\text { STFC } \\
\text { UCL } \\
* \\
\text { University of Bath } \\
\text { University of Bristol } \\
\text { University of Oxford } \\
\text { Radboud University }\end{array}$ & $\begin{array}{l}\text { STFC : Original data retained for the longest possible period | } 10 \text { years after end of project reasonable minimum | } \\
\text { Not re-measurable data: retain in perpetuity } \\
\text { UCL : Min. } 10 \text { years after publication | Plan for custodial responsibilities } \\
\text { University of Bath : Data must be retained for } 10 \text { years. "Researchers should avoid retaining data using methods } \\
\text { that might not persist for } 10 \text { years, such as use of project websites or personal computing equipment." } \\
\text { University of Birmingham : in “Code of Practice for Research" ( } 3 \text { Research Data): } 10 \text { years | clinical, major social, } \\
\text { environmental or heritage importance: } 20 \text { years } \\
\text { University of Bristol : "In order to meet funder requirements around the storage, preservation and accessibility } \\
\text { of research data, unless otherwise agreed the University is expected to keep a copy of any significant research } \\
\text { data for a specified period after the end of the research (generally } 10 \text { years)." } \\
\text { University of Cambridge : As long as data seems to be valuable to data creator or to others, or required by } \\
\text { funder/other regulatory requirements } \\
\text { University of Edinburgh : Research data of future historical interest (and records of University) will be offered } \\
\text { and assessed for deposit and retention } \\
\text { University of Oxford: Min. } 3 \text { years after publication | As long as they are of continuing value } \\
\text { Radboud University : "The retention period for research data is a minimum of ten years." The minimum } \\
\text { retention period for Radboud University is longer than the code of academic practice suggests. A longer minimum } \\
\text { period can be applied by each discipline. A maximum periodcannot be defined, because it is dependent on the } \\
\text { discipline." } \\
\text { Humboldt-Universität zu Berlin : Researchers are committed to secure their research data for the long term }\end{array}$ \\
\hline & $\begin{array}{l}\text { Deletion. It should be } \\
\text { clear how the deletion } \\
\text { of data should be } \\
\text { carried out and who } \\
\text { decides about it }\end{array}$ & $\begin{array}{l}\text { STFC } \\
\text { University of Bath } \\
\text { University of Birmingham } \\
\text { University of Bristol } \\
\text { University of Cambridge } \\
\text { University of Edinburgh } \\
\text { University of Glasgow } \\
\text { University of Leeds } \\
\text { University of the Arts } \\
\text { London } \\
\text { Aalto University }\end{array}$ & $\begin{array}{c}\text { UCL } \\
\text { Tampere University of } \\
\text { Technology }\end{array}$ & University of Oxford & $\begin{array}{l}\text { UCL : Suggests recommendation in DMP for destruction of research data } \\
\text { University of Oxford: Reason: agreed period of retention has expired or legal or ethical reasons | Should be done } \\
\text { in accordance with legal, ethical, research funder and collaborator requirements (confidentiality and security) } \\
\text { Tampere University of Technology : Intentional destruction of data in DMP }\end{array}$ \\
\hline
\end{tabular}




\begin{tabular}{|c|c|c|c|c|}
\hline & $\begin{array}{c}\text { University of Helsinki } \\
\text { University of Turku } \\
\text { Radboud University } \\
\text { Humboldt-Universität zu } \\
\text { Berlin } \\
\text { Universität Bielefeld } \\
\text { Universität Göttingen } \\
\text { Universität Heidelberg }\end{array}$ & & & \\
\hline 16. Legal aspects. & & $\begin{array}{l}\text { UCL } \\
\text { University of Edinburgh } \\
\text { University of Oxford } \\
\text { University of the Arts } \\
\text { London } \\
\text { Radboud University } \\
\text { Humboldt-Universität zu } \\
\text { Berlin } \\
\text { Universität Bielefeld } \\
\text { Universität Göttingen }\end{array}$ & $\begin{array}{l}\text { University of Bath } \\
\text { University of Birmingham } \\
\text { University of Bristol } \\
\text { University of Cambridge } \\
\text { University of Glasgow } \\
\text { University of Leeds } \\
\text { Aalto University } \\
\text { Tampere University of } \\
\text { Technology } \\
\text { University of Helsinki } \\
\text { University of Turku } \\
\text { Universität Heidelberg }\end{array}$ & $\begin{array}{l}\text { STFC : Compromising data integrity (modification of data or incorrect metadata) considered as serious breach of } \\
\text { policy | Users acknowledge source of data } \\
\text { University of Bath : Guidance on selecting licence for research data } \\
\text { University of Bristol :"Researchers must ensure that they abide by licences or terms of use when using or sharing } \\
\text { third party data." | "(..) Exclusive rights to research data must not assigned, licenced or otherwise transferred to } \\
\text { external parties." } \\
\text { University of Cambridge : Intellectual Property Rights } \\
\text { University of Glasgow : Exclusive rights to reuse or publish should not be handed over to commercial publishers } \\
\text { or agents without retaining rights to make data openly available for re-use (unless this is condition of funding) } \\
\text { University of Leeds: Guidance on sharing and publication of research data | Relevant legislative frameworks } \\
\text { Aalto University : Guidelines with "Rules of handling of information materials" | Recommended license for } \\
\text { research data: CC BY } 4.0, \text { metadata: CCO 1.0, software: MIT Licence | User rights of third parties - University may } \\
\text { charge a fee for the use of research data } \\
\text { Tampere University of Technology : Security and data protection | Authors appropriately acknowledged by reuse } \\
\text { | Fee and restrictions on data sets processed for industry or society } \\
\text { University of Helsinki : Good practice for attribution of authorship | University of Helsinki must always be } \\
\text { indicated as the source of data | Fee for data sets processed for business and society } \\
\text { University of Turku: Attribution of authorship | University of Turku must always be indicated as the source of } \\
\text { data | University has at least rights of use | Fee for data sets processed for business and society | Creator's right } \\
\text { to primary use of research data | Commercial utilisation and related protection of rights }\end{array}$ \\
\hline $\begin{array}{l}\text { 17. Ethics. The ethical } \\
\text { use/reuse of data, } \\
\text { particularly how it } \\
\text { affects potential reuse } \\
\text { should be considered }\end{array}$ & $\begin{array}{c}\text { Humboldt-Universität zu } \\
\text { Berlin } \\
* \\
\text { Universität Bielefeld }\end{array}$ & $\begin{array}{l}\text { STFC } \\
\text { UCL } \\
\text { University of Edinburgh } \\
\text { University of Oxford } \\
\text { University of the Arts } \\
\text { London } \\
\text { Tampere University of } \\
\text { Technology } \\
\text { University of Helsinki }\end{array}$ & $\begin{array}{l}\text { University of Bath } \\
\text { University of Birmingham } \\
\text { University of Bristol } \\
\text { University of Cambridge } \\
\text { University of Glasgow } \\
\text { University of Leeds } \\
\text { Aalto University } \\
\text { University of Turku }\end{array}$ & $\begin{array}{l}\text { University of Bristol : University has developed methods to provide controlled access to sensitive data | Ethics of } \\
\text { Research Policy and Procedure } \\
\text { University of Cambridge : Research Ethics Policy } \\
\text { University of Glasgow : Researchers have to ensure that sensitive data is properly managed (Data Protection } \\
\text { Policy, Confidential Data Policy) } \\
\text { University of Leeds: Guidance on good practice in ethics and ethical review } \\
\text { Aalto University : Guidelines for ethical principles, responsible conduct of research and processing of personal } \\
\text { data } \\
\text { University of Helsinki : Protection of confidential information | Data security and protection }\end{array}$ \\
\hline
\end{tabular}




\begin{tabular}{|c|c|c|c|c|c|}
\hline & & & $\begin{array}{l}\text { Radboud University } \\
\text { Universität Göttingen }\end{array}$ & Universität Heidelberg & University of Turku : Processing and preservation of personal data and sensitive material in DMP \\
\hline & $\begin{array}{l}\text { Regulations for: } \\
\text { a) open data } \\
\text { b) restricted data } \\
\text { c) closed data should } \\
\text { be made a subject of } \\
\text { discussion }\end{array}$ & $\begin{array}{l}\text { Radboud University } \\
\text { Universität Bielefeld }\end{array}$ & $\begin{array}{l}\text { UCL } \\
\text { University of Birmingham } \\
\text { University of Bristol } \\
\text { University of Cambridge } \\
\text { University of Edinburgh } \\
\text { University of Oxford } \\
\text { University of the Arts } \\
\text { London } \\
\text { Tampere University of } \\
\text { Technology } \\
\text { University of Helsinki } \\
\text { Humboldt-Universität zu } \\
\text { Berlin } \\
\text { Universität Göttingen } \\
\text { Universität Heidelberg }\end{array}$ & $\begin{array}{c}\text { STFC } \\
\text { University of Bath } \\
\text { University of Glasgow } \\
\text { University of Leeds } \\
\text { Aalto University } \\
\text { University of Turku }\end{array}$ & $\begin{array}{l}\text { STFC : Length of proprietary period specified in DMP | Data publicly available } \\
\text { University of Birmingham : in "Code of Practice for Research" ( } 3 \text { Research Data) } \\
\text { University of Bristol : Open and restricted data mentioned in relation to storage } \\
\text { University of Cambridge : "There is a balance between openness and duties under professional codes and legal } \\
\text { obligations" | Make research data as widely and openly available as possible } \\
\text { University of Glasgow : Publicly funded research data openly available with as few restrictions as possible } \\
\text { Aalto University: Research data is not opened if the opening would violate privacy, safety, security, terms of } \\
\text { project agreements or legitimate concerns of private partners } \\
\text { Tampere University of Technology : All research materials open by default } \\
\text { University of Turku : Leading theme in data policy is openness | Openness can be limited for justified reason }\end{array}$ \\
\hline & $\begin{array}{l}\text { Storage and access. It } \\
\text { should be addressed by } \\
\text { the policy where data } \\
\text { will be stored and how } \\
\text { it will be accessed. }\end{array}$ & Universität Bielefeld & $\begin{array}{l}\text { University of Edinburgh } \\
\text { University of Oxford } \\
\text { University of the Arts } \\
\text { London } \\
\text { Tampere University of } \\
\text { Technology } \\
\text { University of Helsinki } \\
\text { University of Turku } \\
\text { Humboldt-Universität zu } \\
\text { Berlin } \\
\text { Universität Heidelberg }\end{array}$ & $\begin{array}{c}\text { STFC } \\
\text { UCL } \\
\text { University of Bath } \\
\text { University of Birmingham } \\
\text { University of Bristol } \\
\text { University of Cambridge } \\
\text { University of Glasgow } \\
\text { University of Leeds } \\
\text { Aalto University } \\
\text { Radboud University } \\
\text { Universität Göttingen }\end{array}$ & $\begin{array}{l}\text { STFC : Published data to publication available within } 6 \text { months | Use of different repositories } \\
\text { UCL : Research data: attributable, citable, identifiable, retrievable, available, secure (...) | Long-term preservation } \\
\text { University of Bath : Security measures } \\
\text { University of Birmingham : Security of research data } \\
\text { University of Bristol : University's Research Data Repository - limited amount of free storage | Long-term } \\
\text { retention | Statement on how to access supporting data of published outputs should be ensured by researchers | } \\
\text { Information security policies } \\
\text { University of Cambridge : Publicly accessible discipline-based or institutional repository I When depositing } \\
\text { research data into external data repositories, researchers should choose repositories which support Open } \\
\text { Researcher and Contributor ID (ORCID) } \\
\text { University of Edinburgh : National or international data service or domain repository or a University repository } \\
\text { University of Glasgow : Researchers have to: } \\
\text { - "Work with IT Services and College IT teams to identify storage requirements that may exceed that currently } \\
\text { - offered by the institution. } \\
\quad \text { "Store their data during the course of their research in accordance with guidance from IT Services and } \\
\text { funder requirements." } \\
\text { "Deposit data in a reputable repository for long term preservation and sharing." }\end{array}$ \\
\hline
\end{tabular}




\begin{tabular}{|c|c|c|c|c|}
\hline & & & & $\begin{array}{l}\text { I University Services have to "provide a dedicated institutional research data repository with appropriate security } \\
\text { and backup." } \\
\text { University of Leeds: All relevant research data should be offered and assessed for deposit and preservation in an } \\
\text { appropriate University, national or international data service or domain repository: Guidance } \\
\text { University of Oxford : Planning for the ongoing custodianship (at the University or using third party services) of } \\
\text { data after the completion of research or, in event of departure or retirement from the University | Agreement } \\
\text { with the head of department/faculty as to where data will be located and how this will be stored } \\
\text { Aalto University: Research data and necessary software to access data shall be easily accessible | Embargo } \\
\text { period can be agreed upon | Data chosen for long-term preservation shall be safely stored and curated | } \\
\text { Necessary software stored together with research data } \\
\text { Tampere University of Technology : Long-term preservation and reuse | All materials must be retrievable and } \\
\text { citable } \\
\text { University of Helsinki : Discoverybility and citability } \\
\text { University of Turku: Discoverybility and citability } \\
\text { Humboldt-Universität zu Berlin : Long-term preservation | Open Access Declaration } \\
\text { Universität Göttingen : "Storage and archiving of digital research data is carried out within the technological and } \\
\text { informational infrastructure of the University or in acknowledged external or internal subject repositories." } \\
\text { Universität Heidelberg : Long-term preservation | Open-Access-Policy }\end{array}$ \\
\hline 20. Metadata curation. & $\begin{array}{c}\text { University of Bristol } \\
\text { University of Edinburgh } \\
*^{*} \\
\text { University of Leeds } \\
{ }^{*} \\
\text { University of Oxford } \\
{ }^{*} \\
\text { Humboldt-Universität zu } \\
\text { Berlin } \\
* \\
\text { Universität Bielefeld } \\
* \\
\text { Universität Göttingen } \\
\text { Universität Heidelberg }\end{array}$ & $\begin{array}{l}\text { UCL } \\
\text { University of Birmingham } \\
\text { University of the Arts } \\
\text { London } \\
\text { Aalto University }\end{array}$ & $\begin{array}{c}\text { STFC } \\
\text { * } \\
\text { University of Bath } \\
\text { University of Cambridge } \\
* \\
\text { University of Glasgow } \\
\text { * } \\
\text { Tampere University of } \\
\text { Technology } \\
\text { University of Helsinki } \\
* \\
\text { University of Turku } \\
\text { Radboud University }\end{array}$ & $\begin{array}{l}\text { STFC : Sufficient metadata to enable re-use } \\
\text { University of Birmingham : Sufficient metadata description to aid discovery and re-use } \\
\text { University of Cambridge : Metadata Guidance } \\
\text { University of Glasgow : Definition of metadata | Support by the University Services } \\
\text { University of the Arts London : To enable discoverable, accessible and effectively re-use } \\
\text { Tampere University of Technology : Metadata describes structure of data and how it was created | Must specify } \\
\text { owner and legal restrictions } \\
\text { University of Helsinki : Metadata must contain owner and legal restriction } \\
\text { University of Turku: Metadata must contain owner and legal restriction }\end{array}$ \\
\hline $\begin{array}{l}\text { 21. Exceptions. It should } \\
\text { be clear what } \\
\text { exceptions there are in } \\
\text { the policy and what } \\
\text { their extent is }\end{array}$ & $\begin{array}{c}\text { UCL }_{*} \\
\text { University of Cambridge } \\
{ }_{*}^{*} \\
\text { University of Edinburgh } \\
\text { University of Leeds } \\
{ }^{*} \\
\text { Tampere University of } \\
\text { Technology } \\
\text { Humboldt-Universität zu } \\
\text { Hut }\end{array}$ & $\begin{array}{l}\text { University of Birmingham } \\
\text { University of the Arts } \\
\text { London } \\
\text { Aalto University } \\
\text { Radboud University } \\
\text { Universität Göttingen }\end{array}$ & $\begin{array}{l}\text { STFC } \\
\text { University of Bath } \\
\text { University of Bristol } \\
\text { University of Glasgow } \\
\text { University of Oxford } \\
\text { University of Helsinki }\end{array}$ & $\begin{array}{l}\text { University of Bristol : "The policy does not currently apply to taught postgraduate students or undergraduates } \\
\text { (apart from in exceptional circumstances)." } \\
\text { University of Oxford: “(...) Where research is supported by a contract with or a grant to the University that } \\
\text { includes specific provisions regarding ownership, retention of and access to data, the provisions of that } \\
\text { agreement will take precedence." } \\
\text { University of Helsinki : "This policy does not cover the physical resources on which research data are based (e.g., } \\
\text { paper materials) or the use of biological research material." }\end{array}$ \\
\hline
\end{tabular}




\begin{tabular}{|c|c|c|c|c|c|}
\hline & & $\begin{array}{c}\text { Berlin } \\
* * \\
\text { Universität Bielefeld } \\
\text { Universität Heidelberg }\end{array}$ & & University of Turku & $\begin{array}{l}\text { University of Turku: "The data policy does not apply to physical and biological materials and the University's } \\
\text { practises related to them are presented in the research infrastructure policy of the University of Turku." }\end{array}$ \\
\hline 22. & $\begin{array}{l}\text { There should be a } \\
\text { recommendation for } \\
\text { institutional research } \\
\text { infrastructure }\end{array}$ & $\begin{array}{c}\text { STFC } \\
\text { UCL } \\
\text { University of Birmingham } \\
\text { University of Bristol } \\
\text { University of Edinburgh } \\
\text { University of Oxford } \\
* \\
\text { University of the Arts } \\
\text { London } \\
* \\
\text { Humboldt-Universität zu } \\
\text { Berlin } \\
\text { Universität Bielefeld } \\
\text { * } \\
\text { Universität Heidelberg }\end{array}$ & $\begin{array}{l}\text { University of Bath } \\
\text { University of Cambridge } \\
\text { University of Leeds } \\
\text { Aalto University } \\
\text { Universität Göttingen }\end{array}$ & $\begin{array}{l}\text { University of Glasgow } \\
\text { Tampere University of } \\
\text { Technology } \\
\text { University of Helsinki } \\
\text { University of Turku } \\
\text { Radboud University }\end{array}$ & $\begin{array}{l}\text { University of Cambridge : Infrastructure and training to promote best practice in data management amongst } \\
\text { academics } \\
\text { University of Glasgow : Technical infrastructure and services } \\
\text { University of Leeds: Costing and infrastructure planning } \\
\text { Tampere University of Technology: Tools and services } \\
\text { University of Helsinki : Tools and services } \\
\text { University of Turku: Tools and services | "(...) Data infrastructure is built and developed together with national } \\
\text { and international parties, taking into account the services and infrastructures that they offer." } \\
\text { Universität Göttingen : Services for research data infrastructure }\end{array}$ \\
\hline & $\begin{array}{l}\text { Researchers should } \\
\text { know how to deal with: } \\
\text { the long tail of data } \\
\text { the head of project } \\
\text { data }\end{array}$ & $\begin{array}{l}\text { University of Bath } \\
\text { University of Birmingham } \\
\text { University of Bristol } \\
\text { University of Cambridge } \\
\text { University of Edinburgh } \\
\text { University of Glasgow } \\
\text { University of Leeds } \\
\text { University of Oxford } \\
\text { University of the Arts } \\
\text { London } \\
\text { Aalto University } \\
\text { Tampere University of } \\
\text { Technology } \\
\text { University of Helsinki } \\
\text { University of Turku } \\
\text { Radboud University } \\
\text { Humboldt-Universität zu } \\
\text { Berlin } \\
\text { Universität Bielefeld } \\
\text { Universität Göttingen } \\
\text { Universität Heidelberg } \\
\text { * }\end{array}$ & $\begin{array}{l}\text { STFC } \\
\text { UCL }\end{array}$ & & $\begin{array}{l}\text { STFC : Very large data sets } \\
\text { UCL : Curate smaller collections of digital research data }\end{array}$ \\
\hline & $\begin{array}{l}\text { Educational data } \\
\text { should be mentioned } \\
\text { in the policy }\end{array}$ & $\begin{array}{c}* \\
\text { STFC } \\
\text { UCL } \\
\text { University of Bath } \\
\text { University of Birmingham } \\
\text { University of Bristol }\end{array}$ & & & \\
\hline
\end{tabular}




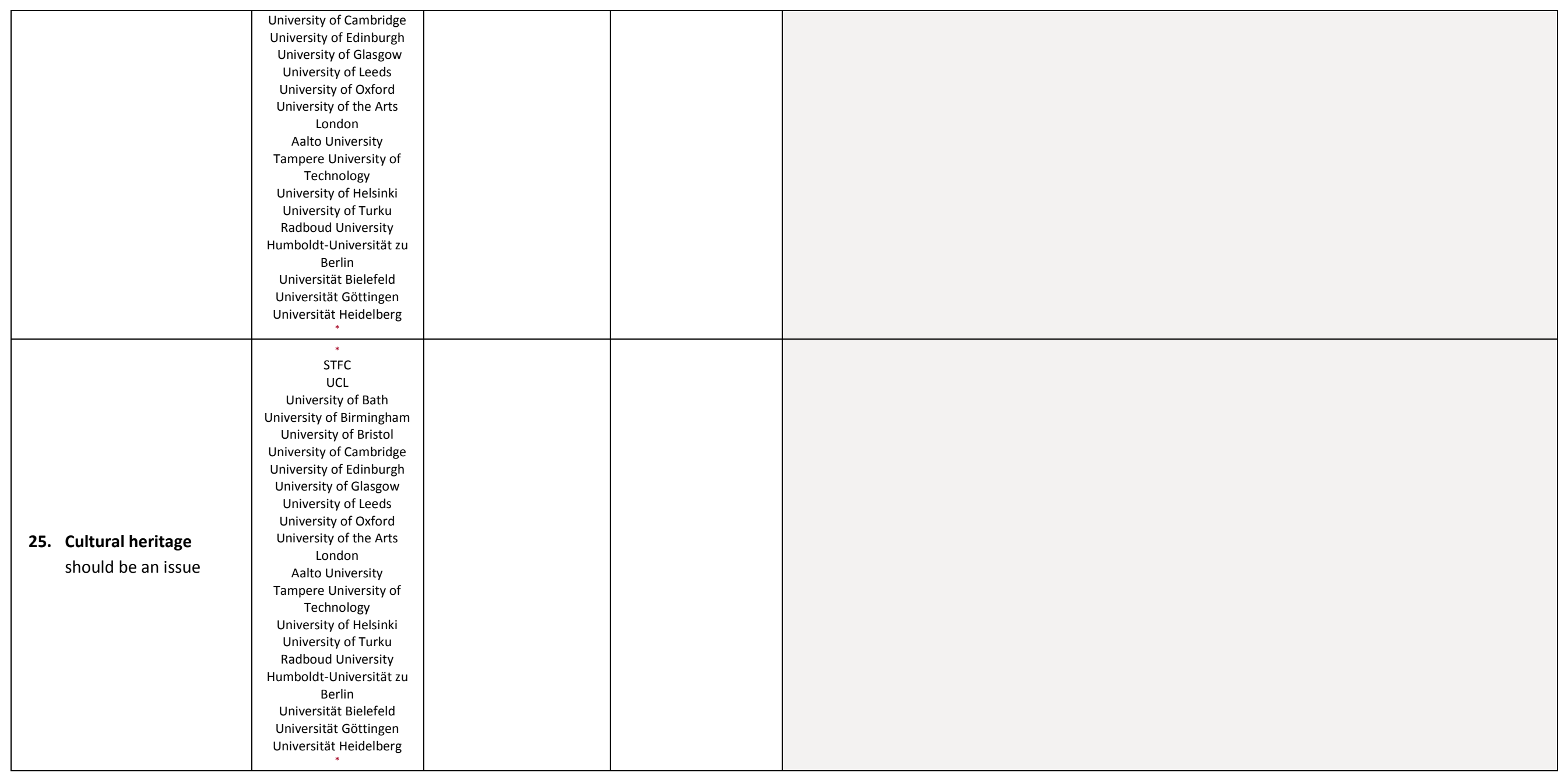


Selected European Policies

STFC (UK) : STFC scientific data policy (?) - (April 2016)

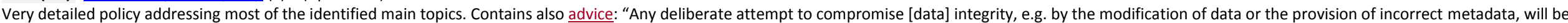
considered as a serious breach of this policy."

UCL - University College London (UK) : UCL Research Data Policy (2 August 2013)

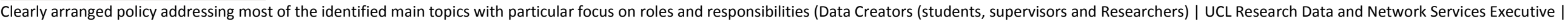
Director of UCL Library Services and UCL Records Manager | RIISG | Vice Provost (Research) | Provost).

\section{University of Bath (UK) : Research Data Policy (9 April 2014)}

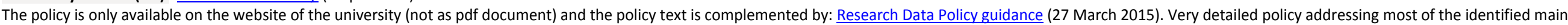
topics. Contains also limitation: "Researchers should avoid retaining data using methods that might not persist for 10 years, such as use of project websites or personal computing equipment."

University of Birmingham (UK) : University RDM policy (May 2014)

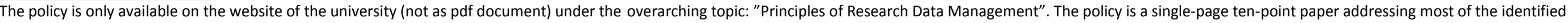
main topics.

University of Bristol (UK) : Research Data Management and Open Data Policy (19 October 2015)

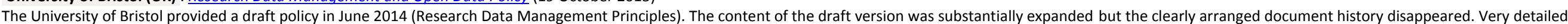

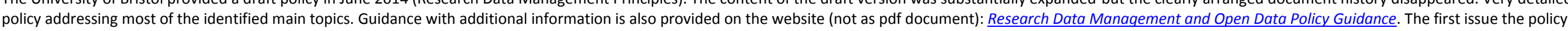

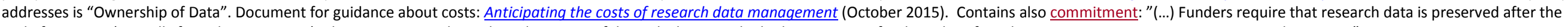
end of a project (typically for at least 10 years). There is a cost to the technical curation of data which cannot be built into project funding, therefore the University is committing to meeting these costs".

University of Cambridge (UK) : Research Data Management Policy Framework (23 April 2015)

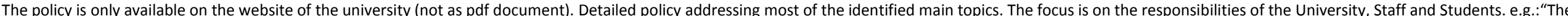

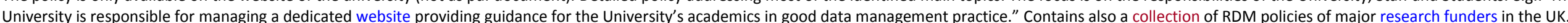

The University of Edinburgh (UK) : Research Data Management Policy (16 May 2011)

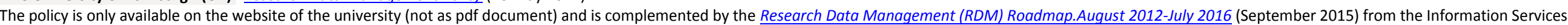
RDM Policy Implementation Committee. It is a 1 page document with 10 points partly addressing a large part of the identified main topics.

\section{University of Glasgow (UK) : Good Management of Research Data Policy (19 November 2015)}

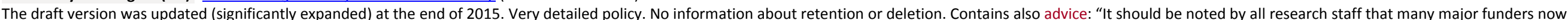

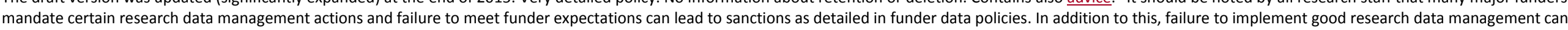
potentially lead to situations which expose researchers to research misconduct allegations.".

University of Leeds (UK) : University of Leeds Research Data Management Policy (June 2015)

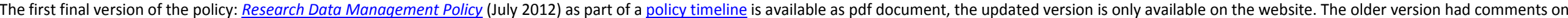

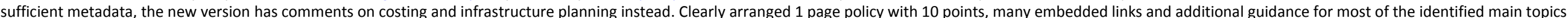
Contains a list of benefits (9) by implementing the policy.

University of Oxford (UK) : Policy on the Management of Research Data and Records (?) - (9 July 2012)

Clearly arranged, precisely formulated policy with 12 points addressing most of the identified main topics. Contains well-defined information about deletion and reference to other university policies. 


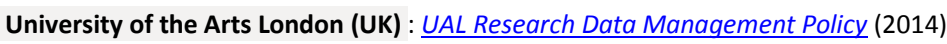

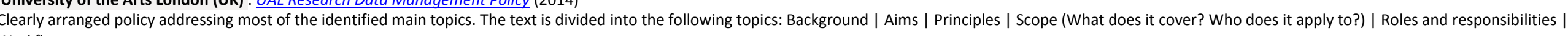
Workflow.

Aalto University (FIN) : Aalto University Research Data Management Policy (10 February 2016)

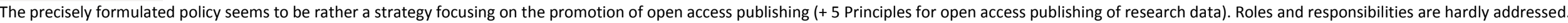

Tampere University of Technology (FIN) : TUT Research data policy (21 January 2016)

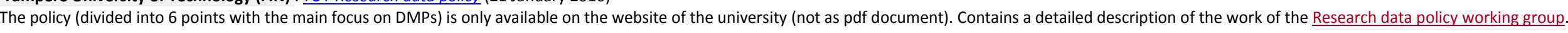

University of Helsinki (FIN) : Research Data Policy (11 February 2015)

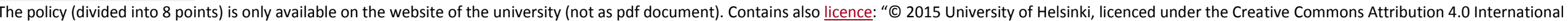
licence". Addresses most of the identified main topics but "Definition" and "Retention".

University of Turku (FIN) : Open science and research data policy of the University of Turku (9 February 2016)

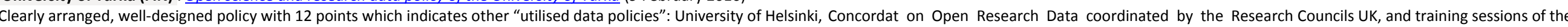

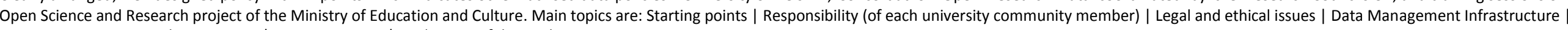
Training, Orientation and Instructions | Communication | Realisation of data policy.

Radboud University (NL) : University policy for storage and management of research data (25 November 2013)

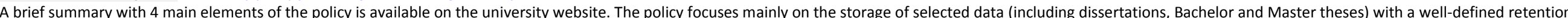

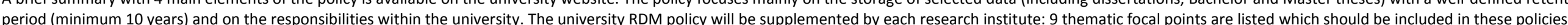

(Responsibilities | Selection on data | Metadata | Storage | Safety of data | Retention | Accessibility and reuse | Privacy of sensitive data | Support and training). Contains also limitation: "The principles of validation and reproducibility imply that storage on a PC/laptop or a mobile device is not an option."

Humboldt-Universität zu Berlin (D) : Humboldt-Universität zu Berlin Research Data Management Policy (8 July 2014)

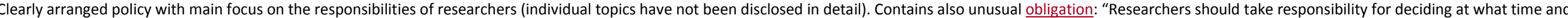
on what legal terms research data may be accessed." The policy is complemented by: Guidelines - A supplement to the Humboldt-Universität zu Berlin Research Data Management Policy (25 August 2014).

Universität Bielefeld (D) : Principles and quidelines on handling research data at Bielefeld University (19 July 2011)

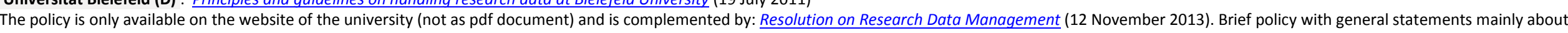
responsibilities.

Universität Göttingen (D) : Research data policy of the Georg-August University Goettingen (incl. UMG) (28 August 2014)

A 1 page document with 10 points partly addressing most of the identified main topics.

Universität Heidelberg (D) : Research Data Policy. Richtlinien für das Management von Forschungsdaten (18 July 2014)

The policy is only available in German on the website, not as pdf document. It deals mainly with legal and ethical issues. 